\title{
KARST WATER RESOURCE MANAGEMENT AND SUSTAINABLE EDUCATIONAL PRACTICES IN NINE YUCATEC MAYA COMMUNITIES
}

Khristin Nicole Landry Montes

Department of Art and Art History, Cornell College, 600 First Street SW, Mount Vernon, Iowa, 52134, USA, klandrymontes@cornellcollege.edu

\section{Patricia A. McAnany}

Department of Anthropology, InHerit: Indigenous Heritage Passed to Present, University of North Carolina at Chapel Hill, 301 Alumni Building CB\#3115, Chapel Hill, North Carolina, 27599, USA, mcanany@email.unc.edu

\section{Dylan J. Clark}

InHerit: Indigenous Heritage Passed to Present, Research Laboratories of Archaeology, University of North Carolina at Chapel Hill, 108 Alumni Building CB\#3120, Chapel Hill, North Carolina, 27599, USA,

dylanc@email.unc.edu

\section{Iván Batún Alpuche}

Professor and Researcher, Universidad de Oriente, Av. Chanyokdzonot, Valladolid, Yucatán, 97780, Mexico, Canek25@hotmail.com

\begin{abstract}
The karst landscape of Yucatán, Mexico is dotted with thousands of sinkholes that provide access to fresh water. These features, called cenotes in Spanish and ts'ono'ot in Yucatec Maya, range from subterranean caverns with well-developed speleothems to open-air sinkholes. While there are a variety of cenote types, all are connected to the subterranean freshwater aquifer. The interconnectivity of cenotes magnifies the impact of cenote contamination. Because of their significance as water sources, cenotes were conceived by ancestral Maya peoples as portals to supernatural forces and guardians of rain. Today, cenotes remain culturally important and are located near the center of most Maya communities, although wells have replaced them as sources of potable water. Many are now developed for tourism and serve as important economic resources. Despite their cultural and economic importance, cenotes are increasingly endangered by contamination caused by industrial and agricultural run-off, trash dumping, chemical and waste contamination, and unsustainable recreational use.
\end{abstract}

One approach to mitigating these threats is through community-driven educational programming aimed at mobilizing youth to study and conserve cenotes in their communities. In 2018, InHerit: Indigenous Heritage Passed to Present, at the University of North Carolina at Chapel Hill, collaborated with students and faculty at the Universidad de Oriente in Valladolid, Yucatán, along with teachers at nine public secondary schools in Maya com- munities, to develop sustainable experiential education curricula related to sinkhole conservation, water quality monitoring, and cultural heritage. Supported by funding from a National Geographic Society grant, students and teachers at nine middle schools participated in this project. Here we discuss the goals and methods employed, as well as how this project is transforming students' ideas about water conservation, and the application of Indigenous knowledge for cenote conservation.

\section{Cenotes and the Yucatan Peninsula Aquifer}

The Yucatán Peninsula, traditional homeland of Mayan-speaking peoples, is a karst plain. This 300,000 square kilometer region includes the Mexican states of Campeche, Yucatán, and Quintana Roo, as well as Belize and northern Guatemala. The porous limestone shelf contains a significant subterranean freshwater aquifer system partly fed by seasonal rains that are quickly absorbed into groundwater. Limestone solution sinkholes, known as ts 'ono 'oto'ob (singular: ts'ono'ot) in the indigenous Yucatec Mayan language and cenotes in Spanish, form when the surface limestone erodes and dissolves, exposing the freshwater beneath that has, over time, carved out channels within the layers of limestone bedrock and sediment that make up the peninsula.

Cenotes themselves can vary significantly in form, from subterranean caverns with well-developed speleothems to open-air sinkholes that appear more like lakes, and even 
"dry" cenotes, known as rejolladas, in which the surface limestone bedrock collapses but does not reach the aquifer. Soils then accumulate in these spaces over time. There are an estimated 2,000 cenotes in the state of Yucatán alone, and perhaps over 7,000 in the region (Beddows et al., 2007, 33; López-Maldonado and Berkes, 2017, 10). The Ring of Cenotes, a unique geohydrological reserve within Yucatán with a high concentration of cenotes and karst groundwater flow, was formed by the impact of the Chicxulub meteor some 65 million years ago and today is included on the tentative list of UNESCO World Heritage sites (Batllori Sampedro, 2017).

Cenotes provide a continual source of freshwater and deeper, more fertile soils in both rainy and dry seasons, and are critical ecosystems that support regional biodiversity and the recharging of the Yucatán Peninsula Aquifer. All cenotes are connected, in the sense that they are or were linked to the aquifer. The Great Maya Aquifer (GAM) research project, also funded by National Geographic, has spent the last decade mapping underwater cave systems in this region and identifying connecting channels that affirm that the Sac Actún system now forms the largest submerged cave known on the planet (Coke, 2019). Moreover, underwater surveys within the aquifer continue to document paleontological and archaeological material of tremendous significance, including extinct megafauna and some of the oldest biological remains of Native Americans in the New World tropics, dating to c.13,000 BP (Anda Alanís, 2010; Chatters et al., 2014).

Considering the geohydrological and climatic characteristics of this environment, it is not surprising that cenotes have been central to Yucatec Maya communities for thousands of years and are still found in or nearby most cities and towns (Figure 1). Also, cenotes always have been important to the cultural and religious life of people in Yucatán. Unfortunately, cenotes and the greater aquifer face significant ecological threats due to industrial pollution, waste disposal contamination, unsustainable tourism development, and climate change.

InHerit: Indigenous Heritage Passed to Present is a university program housed in the Research Labs of Archaeology at the University of North Carolina-Chapel Hill that is dedicated to building grassroots collaborations in archaeology and cultural heritage conservation and education programs with descendent communities throughout the Americas. In 2018, we began a collaborative cultural heritage education and conservation project with nine Yucatec Maya communities and middle schools, along with the Universidad de Oriente in Valladolid, Yucatán. Sponsored by an educational grant from the National Geographic Society, our project was designed to promote conservation of cenotes as unique natural and cultural resources by harnessing the energy and excitement of students aged 11 to 14 through experiential education activities designed around cenotes in their communities. Using a biocultural approach (Gavin et al., 2015) and methods from community-based participatory research (CBPR) we sought to inspire youth to action in order to protect their cenotes for the future. This age group is entering a period of emerging social consciousness, and by engaging them at this time, we believe some will develop a strong conservation ethic around cenotes and carry their knowledge and passion forward. Integrating Indigenous knowledge and traditional appreciation for cenotes with hands-on education was key to our strategy.

\section{Cenotes as Biocultural Patrimony}

Since at least 1000 BCE, Maya populations have lived in complex urban settlements across the lowlands of the Yucatán Peninsula. Some of the more famous archaeological sites in the north include the ancient city of Chichén Itzá that reached its height as a major polity between 950 and $1100 \mathrm{CE}$, ancient T'ho (whose ruins underlie the state capital of Mérida), and the Postclassic Period (1200-late 15th century) city of Mayapán. Smaller cities, such as Tulum on the eastern Caribbean coast, were ports of trade in ancient times and are today major tourist destinations. These ancient cities depended

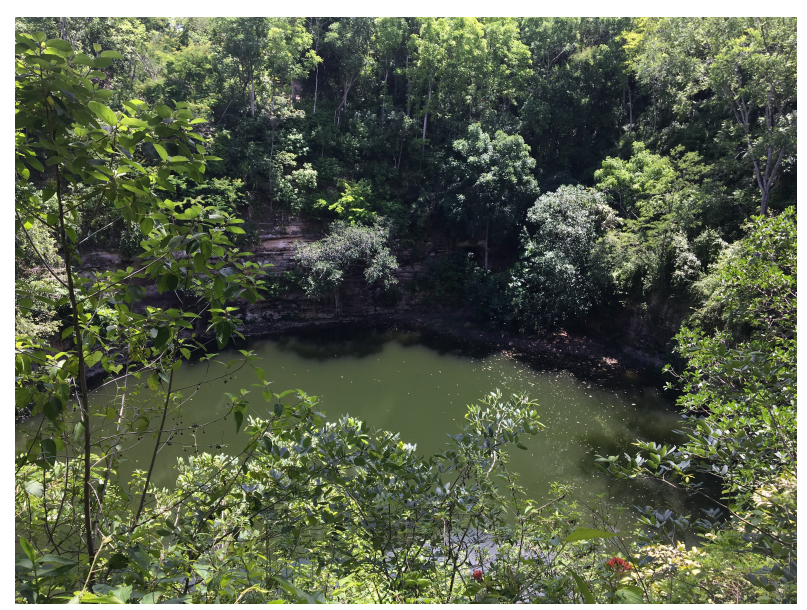

Figure 1. Cenote Yax Ek' in Kava, Yucatan. 
on cenotes as natural springs to provide potable water in lieu of rivers and instead of the brackish lagoons along the coast. At the same time, these watery caves were also celebrated as sacred spaces in the cultural and cosmological landscape.

Strong evidence exists, for example, that the ancient Maya conceptualized cenotes as places that connected the realms of sky, earth, and underworld. At this nexus, supernatural forces and deities could transcend domains and humans could communicate with these forces. Evidence for these associations comes from the many offerings of precious objects as well as human and animal sacrifice found in archaeological excavations in cenotes. For example, Chichén Itzá's large "Sacred Cenote," which was described in historic records from the 16th century as a major pilgrimage site, contains thousands of high value objects made of jadeite, gold, ceramics, wood, and textiles, along with human bones, dating back to at least the 7th century CE (Coggins, 1984;1992). The urban plan of this ancient city and its massive civic-ceremonial center also was guided by the location of cenotes that formed the spatial axes along which the community was organized (Guillermoprieto, 2013).

The earliest Maya codices-books written in the centuries before the Spanish invasion of Yucatán-also provide us with glimpses into the Indigenous worldview surrounding cenotes. These painted books, only four of which escaped the bonfires of Spanish missionaries, show cenotes with patron deities associated with water, rain, and fertility — including the rain god Cháak. As anthropologists Christine Hernández and Gabrielle Vail $(2013,14)$ have demonstrated, cenotes appear frequently in these ancient Maya almanacs because they were associated with agricultural abundance, places of origin and creation, powerful animals like serpents, and rain as a source of sustenance and life $(2013,38)$.

Today, Yucatec Maya people occupy the same landscape and many speak the ancestral language. Some people also practice traditional religious traditions blended with those of Catholicism, especially in relation to agriculture and rain. Cenotes continue to be an important part of these rituals and these features often loom large in traditional stories associated with community origins. Anthropologist Bruce Love (2012) has extensively documented traditional Maya religious practices aimed at bringing water and ensuring agricultural fertility at the end of the dry season. One such ritual, referred to as a Ch'a Cháak (or "rain calling") ceremony is particularly important.

For this ritual, a rectangular altar is set up with specific offerings of sacred materials and prepared foods. Certain trees, small plants, and objects associated with cenotes are placed on the altar as the embodiments of powers of the natural world. At each of the four corners of the altar, four young boys croak, playing the role of supernatural "frogs" in order to call the rain forth from cenotes to the sky and back to earth. This ceremony resembles what we understand from the prehispanic codices in which cenotes - rather than altars - served as the center of the ritual. Frogs and deities are pictured surrounding the cenote and connected to particular dates within the ritual calendar.

Traditional Maya knowledge and cosmovision, like the 2 million or more people who now live in southeastern Mexico, have changed significantly over the centuries, but these examples show us that cenote ecosystems continue to be a complex interweaving of natural and cultural resources - at once essential sources of biodiversity, community history, and cultural identity. These sinkholes are irreplaceable elements of Yucatec Maya biocultural patrimony - a term that refers to their simultaneous biological, ecological, cultural, and historical significance for Indigenous people who have lived in this landscape for millennia. These biocultural resources, however, are increasingly threatened on a number of fronts that include both environmental degradation and a lack of interest (or perceived inability to implement conservation) at the community level (Figure 2). The latter may be the result of on-going distancing of young Yucatecos from traditional knowledge emphasizing the cultural value of cenotes and the interconnectedness of people and nature (López-Maldonado and Berkes, 2017, 15).

As archaeologists and art historians, we have observed that in Mexico, as elsewhere in Latin America, the Indigenous past and perceptions of cultural heritage are entangled with identity politics, nationalism, and economic development in complicated ways that can result in a form of heritage alienation for some communities (McAnany and Parks, 2012). This is an ideological distancing between the archaeological past and Indigenous present, between ancestors and descendants, caused by centuries of reframing heritage discourse in terms of a 
unifying national narrative of racial and ethnic identity that overlays the significant cultural diversity of these countries (Clark and Anderson, 2015, 2).

One of the legacies of colonialism and, later, nationalism is that people who speak Mayan languages today do not always identify as descendants of the people who built the ancient temples and palaces featured at the profitable cultural tourism attractions nearby (Arden, 2004; McAnany, 2016, 71). Local knowledge about natural and cultural patrimony - and the connections between these and the current inhabitants of the landscape and scientific ways of knowing - are often left out of the story in educational curricula. Likewise, cultural anthropologists conducting ethnographic studies of local beliefs and values associated with cenotes have documented a decline, or at least lack of consensus, in speaking about cenotes as sacred or protected by "guardians," or spiritually powerful animals, humans, or deities (López-Maldonado and Berkes, 2017, 12-15).

\section{Current Challenges and the PACECCY Project}

Among the conservation challenges affecting the Yucatán Peninsula aquifer are industrial farming, pesticide pollution, waste contamination, climate change, and unsustainable tourism development. Environmental impact studies have shown that there is a correlation between the location of large, industrial pig farms and the hydrogeological units at risk for aquifer contamination through the water table (López-Maldonado and Berkes, 2017). In more rural areas, cenotes and the aquifer are at risk of pollution from run-off from agricultural fields where pesticides are utilized. Based on our initial observations this year, many cenotes located in both small villages and cities have become dumping grounds for trash, including empty pesticide bottles and lithium batteries. In some localities, domestic wastewater is routed directly into cenotes that are no longer used (or perceived not to be used) for freshwater (this was also observed during the initial phases of our project).

As the resident population continues to rise in the Yucatán Peninsula, both permanently and seasonally with the influx of tourists, the aquifer is further strained to provide sufficient tap water. The increase in extreme weather events that impact the region due to global climate change-whether droughts or hurricanes - also pose a significant threat to the delicate balance between

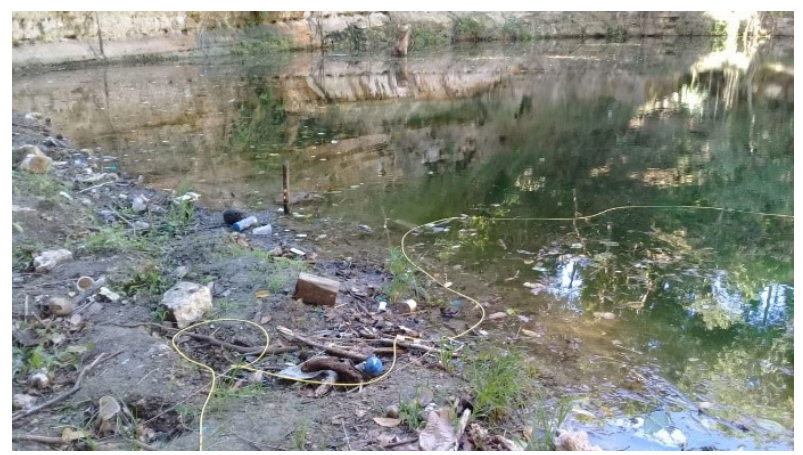

Figure 2. Trash in Cenote Yax Ek', Kava, Yucatan.

freshwater and saltwater above and below the halocline layer of the aquifer. Coastal storm surges also increase the likelihood of chemical contaminants entering the groundwater, creating additional stress on this vital resource.

Furthermore, the increasingly important role that cenotes are playing in cultural tourism development in the region is a double-edged sword. On the one hand, tourist interest in visiting and swimming in cenotes has provided strong impetus for cleaning them up, passing legislation to protect and manage them through state agencies, and generating employment opportunities for communities. On the other hand, this also results in more cenotes being purchased by private individuals and corporations, reduction in access for local people, and destructive alteration of the physical structure of the cave or cenote to accommodate tourism infrastructure or change visual aesthetics. Cenote ecosystems have also been negatively impacted by the chemicals visitors wear into the water and the materials they leave behind.

Mitigating these threats requires both top-down policy changes and grassroots, community-driven initiatives. In 2018 InHerit began a cultural heritage education initiative called Cultural Heritage, Ecology, and Conservation of Yucatec Cenotes, known by its Spanish acronym PACECCY, in order to increase community interest and engagement with cenotes and water conservation at the local level, building on Indigenous knowledge and cultural appreciation to strengthen educational intervention through participatory science, history, and art. We agree with López-Maldonado and Berkes $(2017,11)$ that conservation efforts that build on traditional cultural values and intergenerational bridging of youth with elders and teachers will lead to more sustainable positive outcomes. Our objectives were to collaborate with middle school 
teachers in nine Yucatec Maya communities to create innovative, experiential education curriculum materials designed to raise awareness of the ecological and cultural importance and vulnerability of cenotes, including their role in Maya history and literature.

This methodology involves a form of braiding knowledge, an approach advocated by archaeologist Sonya Atalay (n.d.; 2012) that interweaves scientific research and methods with local knowledge and experience, in this case to work synergistically toward shared goals of resource protection and management. Drawing upon the multiple complementary elements of Indigenous and Western knowledge systems, this approach gives Indigenous communities agency to interpret, monitor, and conserve sinkhole ecosystems. An equally important outcome we sought through this program with teachers and students was "repatrimonialization," in which people reconnect with their local cenotes as part of their biocultural heritage, that is integral to their communities and their stories - past, present, and future.

\section{Project Methods and Results}

In both collaborative archaeology and this multi-component educational and environmental conservation project, we incorporate methods from CBPR that emphasize breaking down colonial power structures when it comes to exploring and assigning meaning to the past. This process encourages dialogue and engagement between different participants at discrete stages of the investigation, creating points of intersection for bi-directional knowledge exchange (McAnany, 2016, 132). A communitybased cultural heritage project brings descendent communities' voices into the process at the level of research design-from decisions about what research questions and interpretative strategies to pursue to the methodological approaches and kinds of evidence used to address these questions. This framework has guided our approach with the PACECCY project.

PACECCY is especially focused on creating experiential learning opportunities through the study of oral history and folklore, science and safety, and the archaeology and heritage of cenotes. PACECCY is a collaborative effort among Inherit, Universidad de Oriente (UNO) in Valladolid, Yucatán, and the communities and secondary schools of Tixhualactún, Kaua, Yalcobá, Tikuch, Calotmul, Tahcabo, Cuncunul, Xocen, and Hunukú. Altogether, the team is composed of archaeologists, oral histo- rians, archivists, art historians, middle school educators and directors, and university and middle school students.

We chose the nine schools selected for the PACECCY project based on the presence of a cenote in each community, proximity to Valladolid where UNO is located, and interest in participating on the part of the community (Figure 3). Early in the project, we worked with 1-2 teachers and the director (principal) from each school to gauge students' existing knowledge and interest in cenotes. We then collaborated with community teachers and directors to create and implement curriculum resources, informed not only by academic and scientific experts, but also by the interests of the students. After one round of in-school implementation, we designed workbooks that incorporate many of the activities we created and the teachers implemented in 2018, as well as background information on cenotes. These processes are discussed more fully below.

Following Atalay's $(2012,3)$ central tenant to "value information and ways of knowing contributed from diverse knowledge systems," our methods focused on creating sustainable and equal partnerships between communities and outside scholars that were steered by the communities and what mattered to them.

With these goals in mind, our team organized the overall project into these six stages:

1. A planning stage through March of 2018 during which time which we created an advisory board of teachers and directors from participating communities.

2. A pre-project assessment stage using surveys and photovoice in a sample of schools to understand students' perspectives on community cenotes.

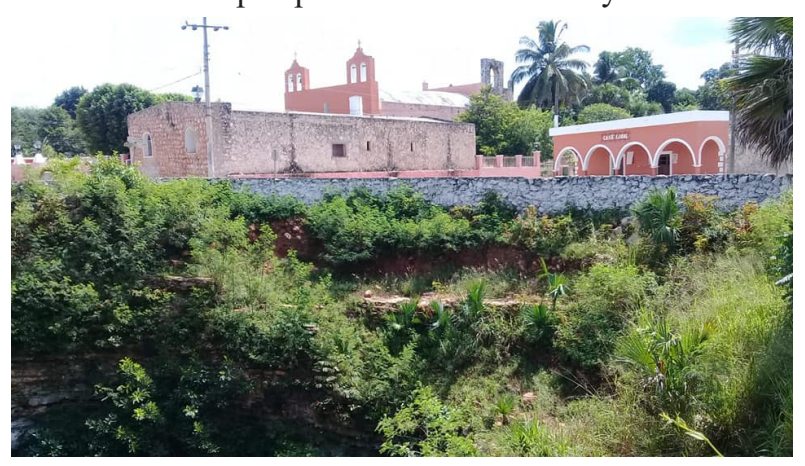

Figure 3. The edge of a centrally located cenote in Cuncunul, Yucatan. 
3. A workshop stage in which three professional development events - designed and carried out for teachers and university students - took place and were based on topics related to cenotes as biocultural resources.

4. A stage during which we worked with teachers and researchers to design experiential education activities related to cenotes and the topics discussed in the educator workshops. This was followed by the implementation of those activities in participating schools.

5. A post-implementation stage during which time we designed assessment surveys and concluded activities in the schools.

6. A writing stage to create and publish workbooks containing background, teaching modules, and experiential education activities related to cenotes.

Each of these stages allowed for the interchange of ideas and practices among project participants. They also offered opportunities for the project team to obtain ideas from middle school students both before and after experiential learning activities were implemented. Such information was invaluable throughout the course of our time in the schools, as well as during the creation of the workbooks. In the following sections, we discuss a selection of these stages more fully.

\section{Planning, Photovoice, and Pre-Project Assess- ment}

Planning for PACECCY began in January 2018 and was initially guided by InHerit staff at the University of North Carolina, as well as by faculty and students from the Universidad de Oriente in Valladolid, Yucatán. Dr. Patricia A. McAnany, Kenan Eminent professor of anthropology at the University of North Carolina, served as Principal Investigator for the project with Dr. Dylan Clark, InHerit Program Director, serving as one of the project's co-coordinators. The project's Mexico-based coordinator was archaeologist Dr. Iván Batún Alpuche who led the project from the Universidad de Oriente (UNO). Dr. Khristin Landry Montes, assistant professor of art history at Cornell College, served as Project Facilitator and was a key on-the-ground connection with Batún, bridging the Yucatán- and U.S.-based teams. The Project Facilitator also developed connections with school teachers and directors in Yucatán and coordinated the implementation of experiential learning in the schools.
Nine undergraduate public administration student ambassadors were selected as student ambassadors from UNO for this project. Several of these students speak Mayan in addition to Spanish and English and all grew up in eastern Yucatan. They served as points of contact and facilitated ongoing communication with communities' teachers and staff. Each of the UNO ambassadors worked with one of the nine community schools. Their roles were to facilitate conversation between teachers and the rest of the PACECCY team, to help support the implementation of activities in the schools, and to attend and aid in the teachers' workshops (Figure 4). These students also helped with translation from Yucatec Mayan to Spanish, as well as from Spanish to English. As young adults from Yucatán, several of whom are Maya themselves, the most important and overarching role of the UNO ambassadors was to support and carry forward the energy of the project into the future.

Prior to the first professional development workshop, project staff and teachers serving on our advisory board collaborated to design survey questions for students in order to gauge their baseline knowledge of cenotes, the aquifer system, and what these biocultural resources meant to them and their communities. This was an important component of the pre-project assessment that guided subsequent components. For some survey questions, students were also asked to draw what they knew or thought about cenotes. These surveys were given to students with instructions that we wanted to see what they knew about the cenotes in their own communities and what they wanted to learn more about. In addition to the survey, we employed an assessment technique from CBPR called photovoice in four of the nine communities.

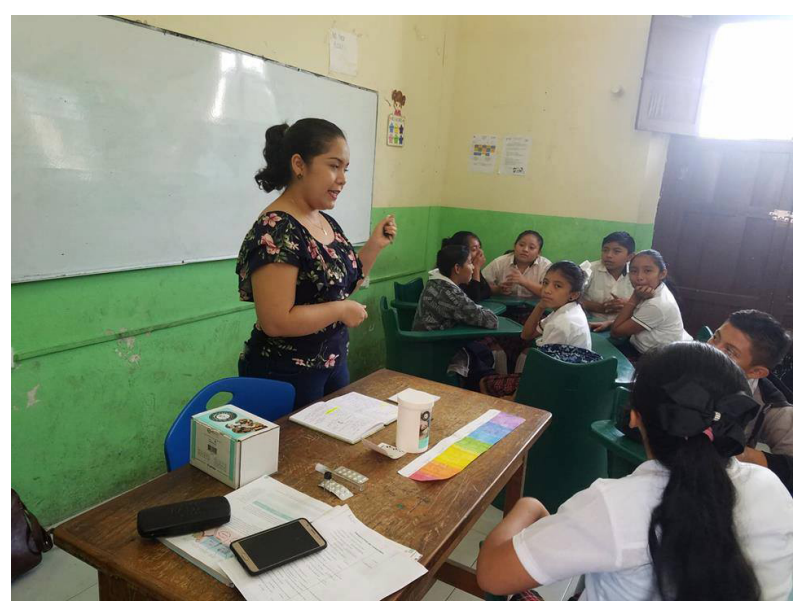

Figure 4. UNO Ambassador Yaremi Tuz May leading a water quality testing activity with students in Cuncunul, Yucatan. 
Photovoice involves distributing cameras to members of the community - in our case middle school studentsand asking them to take pictures of their cenote(s). Students then reconvened and discussed their photographs as a group. A major strength of this technique is that it gives agency to community members to explore localized strengths and concerns, while also promoting dialogue between the various project participants. Beyond our own project, photovoice has been used successfully in other applied anthropology projects (Dedrick, 2018), as well as in public health research (Wang and Burris, 1997; Thelen and Morgan, 2015).

In our photovoice activities, students, together with project staff and their teachers, traveled to the cenote nearest the community to take pictures (Figure 5). Students were given digital cameras and instructed to take photos of anything they wanted, as long as photos could be linked thematically to a cenote. After the first photo sessions, we downloaded the pictures into computers and printed the photos for the discussion session that followed. Then, in the first photovoice discussion session, students were provided with their printed photographs and asked to select two photos to write about and discuss. They had roughly $8-10$ minutes to write freely and then they presented their photographs with their written thoughts to the rest of the group. They were asked what had inspired them to photo-document a particular aspect of a cenote in the manner they did.

Researchers then engaged with students by asking openended questions to facilitate discussion of photographs. We found that certain themes naturally came to the forefront during these discussions and so- - together with the students - we identified specific areas of focus for the next photo session that emphasized these themes of interest. We then went back to the cenote for Photo Session \#2. For this session, students were asked to focus their attention and their cameras on the themes we identified in the discussion of photographs in the previous session. After this photo session was completed, we followed a similar process to Photo Session \#1 and met students for a second and final discussion session in order to share the photos that were produced from the second photo session.

Both surveys and photovoice activities allowed our team and teachers to understand what students already knew about cenotes and also what they wanted to know more about. The image-based activities, including the survey drawings and photovoice images, showed us what students were focusing on in relationship to their community cenotes and what they viewed as important. Many of the photos that were taken, for example, were of trash in and around the cenotes. From these photos and the discussions that followed, we found that contamination and pollution were of central concern to students. From the many images of stalactites and stalagmites, as well as plants and animals, it also was clear that students were interested in geology and cenotes as ecosystems filled with life.

Surveys echoed these interests, and students often wrote about wanting to know more about cenote formation, the kinds of plants and animals that live inside cenotes, how cenotes related to stories they had heard and how cenotes figured into their Maya ancestral past. Importantly, this activity re-ignited students' interest in traditional knowledge related to the oral history of cenotes before any classroom curriculum materials were even fully

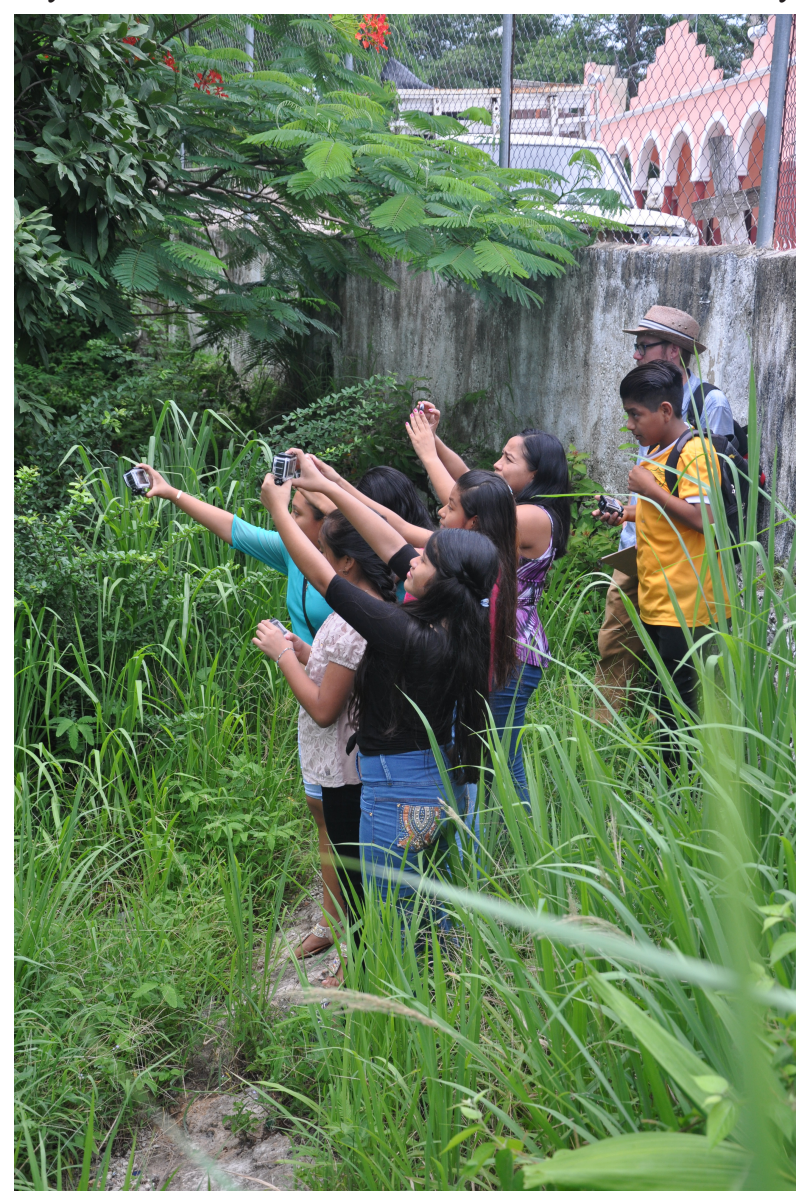

Figure 5. Students from Yalcoba, Yucatan taking pictures of their cenote for photovoice. 
designed, bringing local cultural knowledge and ethnographic approaches directly into the planning phase of the project.

Moreover, this activity also served to bridge different generations within the same community, as students were more motivated to speak with elders and to compare diverse explanations for the hydrology and plant life of cenotes. Surveys and photovoice also served to reshape the direction of educator workshops and the curriculum materials we designed with an eye to the interests and viewpoints of young community members. Some of the topics that resonated most with students became central themes around which we built the educator workshops, especially oral history and traditions, chemistry, plant and animal biology, and ancient Maya painted manuscripts, or codices.

\section{Advisory Board Meetings and Teachers' Work- shops}

During and after photovoice activities, the community advisory board, consisting of the project staff, school directors and 1-2 teachers from each school, met to discuss project assessment and plans for the next stages. Together, with the results from student surveys and photovoice in mind, the advisory board helped design three educational and interactive workshops for teachers and student ambassadors that would take place at UNO. Each of these capacity-building workshops were designed around broad topics with specific curriculum and themes. The overall goal of the workshops was to bring teachers and researchers together to share knowledge and generate curriculum activities for students that were focused on cenote conservation and aligned with student interests and curiosities. The three workshop themes included (1) oral history and folklore, (2) science and safety, and (3) archaeology and heritage of cenotes. The workshops created transcultural spaces with opportunities for knowledge sharing in multiple directions between university students and researchers and secondary school teachers. The workshops are more fully described below.

For Workshop 1: Oral History and Folklore, we incorporated training and use of oral history backpacks that contained voice recorders, notebooks and pencils, as well as flashcards with vocabulary and starter questions to aid students in conducting oral histories with members of their communities (especially as those histories related to cenotes). The workshop was led by experts in the fields of community-driven archives, oral history, and Maya literature. As a way to encourage Indigenous storytelling and use of the Yucatec Mayan language, flashcards were bilingual in both Yucatec Mayan and Spanish and included vocabulary for various things associated with cenotes (animals, plants, rock formations, etc.), as well as helpful prompts for asking questions in an oral history interview. At the end of the workshop, teachers were given two backpacks to take back to their schools for use during the subsequent implementation phase, as well as in the future.

For Workshop 2: Science and Safety, teacher training focused on the geology and biology (flora \& fauna) of cenotes, water conservation and aquifer hydrology, and the safety and legal protection for cenotes at the state level. Experts in each of these fields from Yucatán led the sessions. Also, teachers were introduced to educational water-quality test kits provided by the NGO EarthEcho International. Together with two OpenROV submersible drones, the test kits were used by classes to conduct citizen- science projects involving water quality monitoring and underwater exploration of their community cenotes.

The final Workshop 3-Archaeology and Heritage-focused on cenotes as important and irreplaceable cultural resources as well as part of an inherited Maya past. Invited speakers from both Mexico and the U.S. discussed the archaeology of cenotes, including the significant archaeological finds that have been recovered from them, as well as their presence and meaning in the ancestral Maya codices (Figure 6). The workshop also discussed cenotes as important elements in Maya cosmovision and as parts of sacred landscapes both in the past and today. In the spirit of Paolo Freire's (1970) critical pedagogy, secondary school teachers and directors discussed both theoretical and historical perspectives on pedagogical approaches to biocultural patrimony in Yucatán's secondary schools today.

Invited guest speakers, each an expert on a given topical area, were invited to attend and lead and/or facilitate the workshops. Each of the workshops were attended by teachers, school directors, project staff, and UNO students and encouraged dialogue about mechanisms for integrating these topics and curriculum resources into classroom activities. These workshops helped the group decide which experiential activities would be most use- 


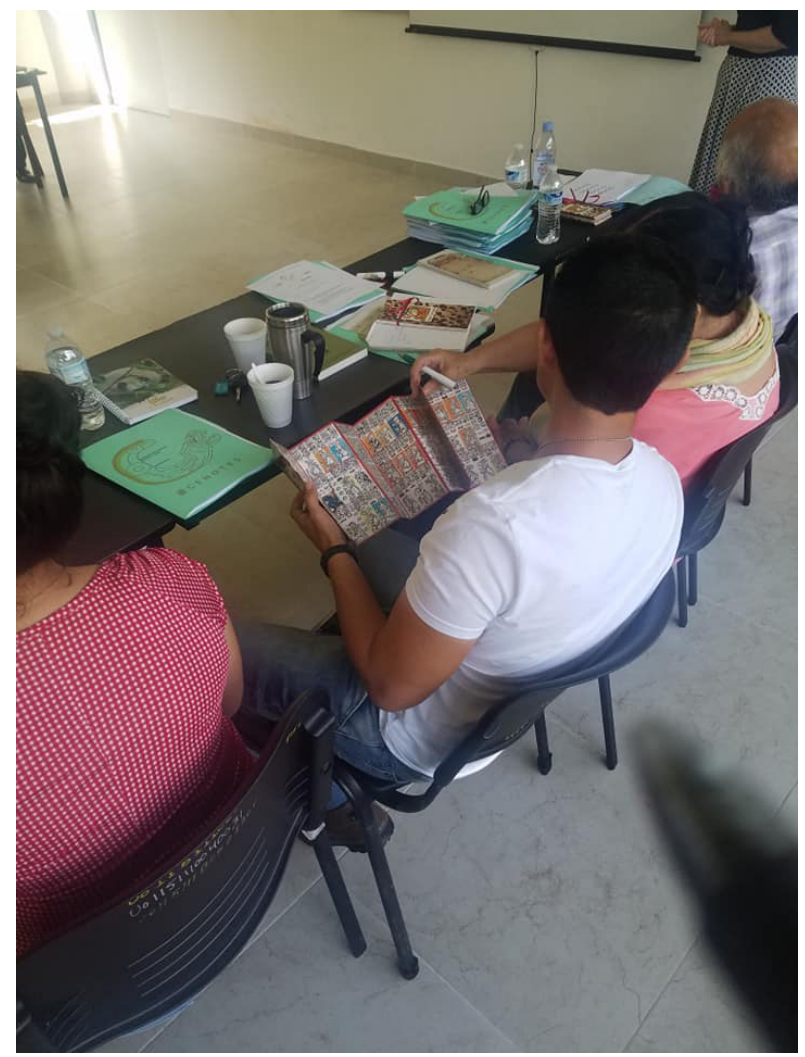

Figure 6. Teachers working with facsimiles of the ancient Maya codices in Workshop 3.

ful to implement with middle school students in the subsequent implementation phase.

\section{Implementation}

The implementation phase of the project began in late August of 2018. Teachers and project staff worked together to schedule meetings with classes in order to undertake experiential learning activities. The learning activities implemented during this phase were largely based on the training teachers had received in the three educator workshops. Teachers worked with the Project Facilitator Landry-Montes, co-director Batún Alpuche, and the nine UNO student ambassadors to schedule times and days for students to engage in activities. By encouraging UNO students to lead activities, we created an opportunity for local young adults to take the lead in sharing knowledge and inspiring a new generation of Maya students. In our work together with middle school teachers, we facilitated the following programming involving experiential learning that grew from the teachers' workshops:

Oral History and Folklore Concentration: Students from each of the nine schools learned about oral history, Maya oral and literary traditions, and how to conduct oral history interviews. Then, they conducted their own interviews with family members and elders in their communities, using the oral history backpacks. Many students chose to interview family members with digital voice recorders about their experiences with local cenotes and the stories surrounding them. Students reported to their class about what they discovered through the interview process. Other classes preferred conducting interviews as a group. In one case, students interviewed a local j'men - traditional Maya healer-about his knowledge of and experiences with a local cenote. The entire class attended this event. One student asked questions (in the Yucatec Mayan language) from the oral history flash cards while another took notes on the conversation. Other students translated the Maya conversation into Spanish as part of their class project.

Science and Safety Concentration: Students from each of the nine schools had class periods in which they were trained in the importance of testing for water quality in the cenotes. They used EarthEcho and LaMotte educational water quality testing kits to study the water quality of the cenotes in and near their communities. Specifically, students tested for $\mathrm{pH}$, dissolved oxygen, temperature, and turbidity (Figure 7). As part of this exercise, students participated in EarthEcho's online Water Challenge by uploading data from their water quality tests to the EarthEcho International website and comparing them with information from students participating in the same citizen-science activity across the globe. In some cases, and if safety permitted, students were also able to submerge and drive underwater drones that were obtained for our project from OpenROV. The drones took video, as well as depth and temperature readings. The students could see underwater animals and geomorphic

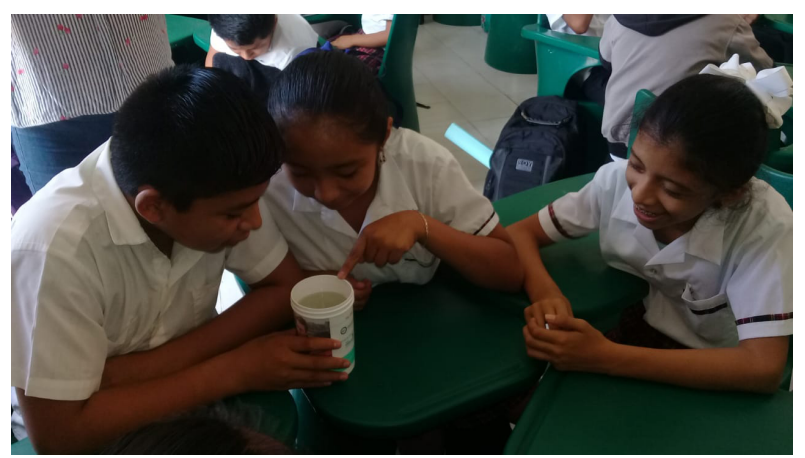

Figure 7. Students perform water quality tests from their community cenote in Cuncunul, Yucatan. 
features inside the cenotes, and participated in recording and archiving the video along with measures of depth and temperature. In this manner, students not only obtained and compared water quality data, they also got a glimpse of what cenotes look like from within, including the life they contain, and the unfortunate truth that many also contain trash and other contaminants.

Archaeology and Folklore Concentration: Students from each of the nine schools also had classes that focused on the history of cenotes in relation to the cultural traditions of ancestral Maya peoples. We concentrated especially on how cenote imagery and cultural value are manifested in ancient Maya books and as part of a cosmovision that includes sacred landscapes. For these sessions, students worked with facsimiles of two of the four existing prehispanic Maya codices - the Dresden Codex and the Madrid Codex. Students identified images of cenotes and deities related to cenotes in these manuscripts, and also learned to read simple hieroglyphic structures and dates. Additionally, students learned about the history of the codices and why cenotes often are depicted in them. Such curriculum emphasized what the codices can tell us about how important cenotes were in ancient Maya religion and the sacred landscapes they occupy today. As part of their experiential learning activities, students made their own cenote-focused codices in the ancient Maya style complete with patron deities, dates, and names written in Maya hieroglyphs (Figure 8).

\section{Post-Implementation Assessment, Workbooks, and Conclusions Post-Implementation Assessment}

The implementation stage was completed in mid-December of 2018, at which point our team initiated a post-project assessment stage. At this point we provided surveys to students to assess what they had learned. Some questions were open-ended and focused on what they might do to improve education in their communities about cenote history and conservation. Teachers also were provided with a questionnaire that requested feedback and asked them to identify and elaborate on the general and specific applicability of the themes for their middle school classes as well as the strengths and weaknesses of the program. This stage allowed us to reflect on the project once more and think about how programming could be improved to be even more useful and integrated into curricula at a greater number of schools in the region. The project team and teachers also used this time to plan the workbooks that would be created in the coming months.

\section{The Workbooks}

The workbooks created from this project are organized around the experiential learning activities that were undertaken throughout the year, as well as new activities that were inspired by those implemented in the pilot year of this initiative. The workbook units and their contents follow the main themes and concentration areas of the project, including: Geology and Hydrology, Oral Histories, Plants and Animals, the Maya Codices, Traditions and Sacred Landscapes, Archaeology and Biocultural Patrimony, and Caring for our Cenotes. Each unit includes background information on the topic, along with relevant lesson plans for the experiential learning activities that students took part in during implementation. Additional resources and ways to order more supplies (e.g., water quality test kits) are given at the end of each chapter.

\section{Conclusions}

We found that the steps and processes laid out above created a multifaceted context around which different members of our team - from students to teachers to university affiliates - could intertwine their knowledge and experiences together through the common goal of energizing secondary school students to be thoughtful and proactive stewards for their communities' cenotes. Initial planning between faculty and staff from InHerit and faculty and students at UNO provided opportunities for community collaboration early on in the process. Teacher workshops and advisory board meetings involving middle school teachers, as well as field experts, allowed us to create environments for capacity building and new opportunities for everyone involved to be active leaders and contributors in shaping an educational approach to sustainable conservation.

These workshops and meetings, as well as active engagement in the classroom during the implementation phase, provided the chance to incorporate different kinds of information and ways of knowing. Much of the educational content produced was community driven and shaped by the students themselves. For example, early surveys and the use of photovoice allowed us to obtain, in both written and visual form, the perspectives of Maya youth on cenotes. These perspectives guided much of the organization and selection of activities that followed. Simi- 


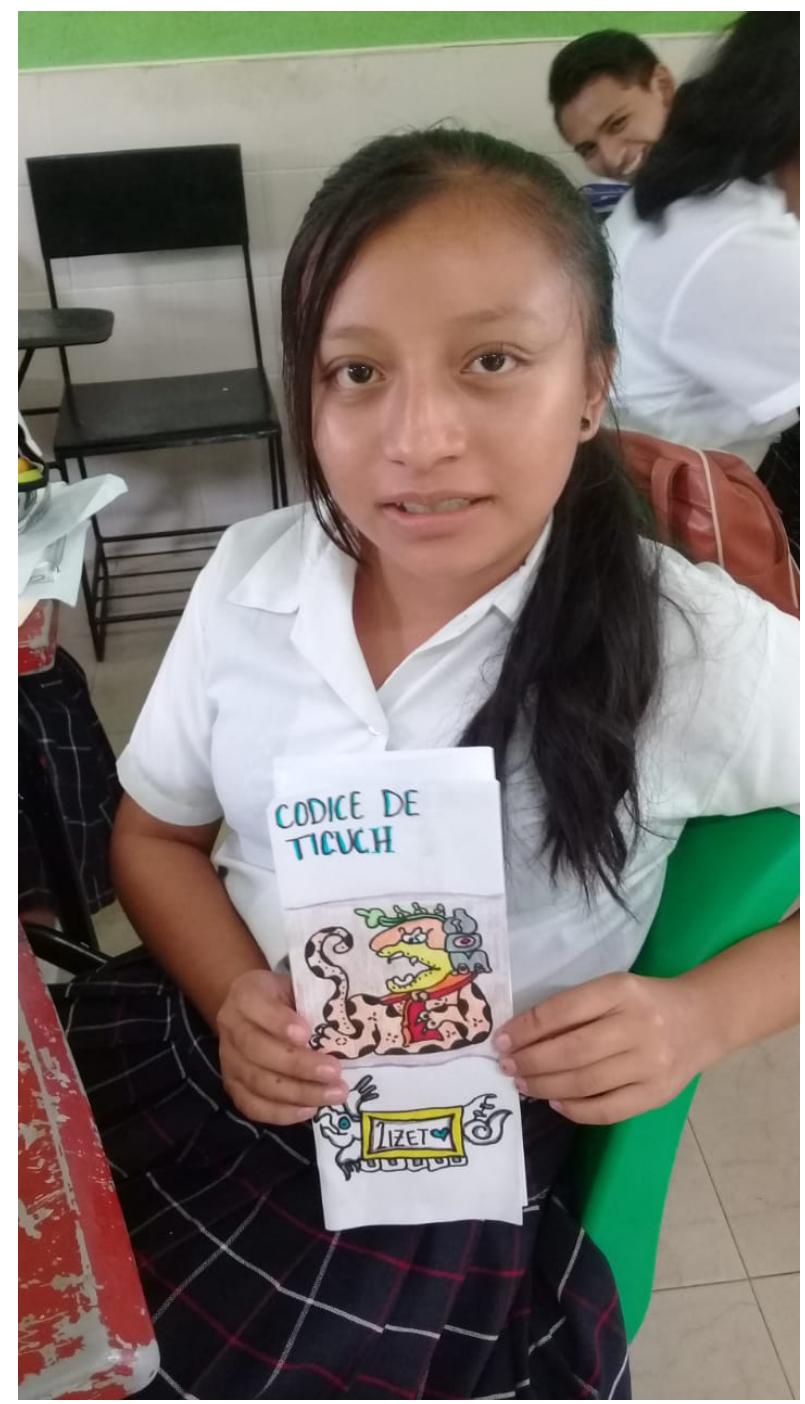

Figure 8. Students from Ticuch, Yucatan made their own codices to highlight the story of their community's cenote.

larly, listening to what the teachers wanted and needed for their classrooms helped to make the development and sustainability of a new cenotes-centered, biocultural patrimony curriculum a success. During the workshops and especially in their classrooms, teachers were active in designing activities that fit the needs and also the constraints of their specific school environments.

An unexpected outcome of the project was that some students were highly motivated to design and implement their own cenote conservation and clean-up projects, along with Maya codices workshops, as extracurricular "clubs" that spun off from class activities. This is just a small indication that students and teachers are embracing patrimonialization and driving forward on re-connecting with local biocultural resources and cenotes as important elements of Maya sacred landscapes.

Ultimately, we believe the project promotes interconnectivity. It recognizes multivocality, while simultaneously the intentionality of collaborators in selecting the strands - data, methods, and epistemologies - that they work to weave together. Through InHerit we strive to promote conversations that support a paradigm shift in academia toward community-based participatory research as a way of transforming and decolonizing the social sciences in order to make the results more applicable to addressing the needs of the communities - in this case, conservation of the aquifer and cenotes. We anticipate that the Cultural Heritage, Ecology, and Conservation of Yucatec Cenotes project will serve as a model for future cultural heritage education projects aimed at supporting and mobilizing indigenous heritage for positive and sustainable change.

\section{Acknowledgements}

We would like to thank the National Geographic Society for the substantial funding they provided in support of this project, as well as the many private donors and supporters who contributed to the success of PACECCY. These include the Southern Historical Collection at the Wilson Library at UNC-Chapel Hill, EarthEcho International, OpenROV, the Ministry of Urban Development and Environment of Yucatán, Mexico (SEDUMA), the Secretary of Public Education of Yucatán, Mexico (SEGEY), faculty and students at the Universidad de Oriente, our invited team of content experts from both Mexico and the U.S., and, of course, the directors, teachers, and students and their families from the secondary schools and communities of Tixhualactún, Kaua, Yalcobá, Tikuch, Calotmul, Tahcabo, Cuncunul, Xocen, and Hunukú.

\section{References}

de Anda Alanís G. 2010. En los profundos dominios de los dioses: arqueología subacuática en Yucatán. In En los antiguos reinos del juagar, edited by Lilia Fernández Souza, 133-145. Mérida: Secretaria de Educación del Gobierno de Yucatán.

Ardren T. 2004. Where are the Maya in Ancient Maya Archaeological Tourism? Advertising and the Appropriation of Culture. In Marketing Heritage: Archaeology and the Consumption of the Past, 
edited by Yorke Rowan and Uzi Baram, 103-16. Walnut Creek, CA: Altamira Press.

Atalay S. n.d. Braiding Knowledge: Critical Issues and Future Challenges in Transforming Scholarship. Submission date for external review: December 1, 2015.

Atalay S. 2012. Community-Based Archaeology: Research with, by and for Indigenous and Local Communities. Berkeley, CA: University of California Press.

Batllori Sampedro E. 2017. Reserva geohidrológica del anillo de los cenotes. In Cenotes y Grutas de Yucatán, edited by Wendy Piña García y Félix Ucán Salazar, 229-240. Mérida: Compañía Editorial de la Península, SEDUMA.

Beddows P, Blanchon P, Escobar E, Torres-Talamante O. 2007. Los cenotes de la península de Yucatán. Arqeuología Mexicana 14 (83) :32-35.

Chatters JC, Kennett DJ, Asmerom Y, Kemp BM, Polyak V, Nava Blank A, Beddows PA, Reinhardt E, Arroyo-Cabrales J, Bolnick DA, Malhi RS, Culleton BJ, Luna Erreguerena P, Rissolo D, Morell-Hart S, Stafford TW Jr. 2014. Late Pleistocene Human Skeleton and mtDNA Link Paleoamericans and Modern Native Americans. Science 344 (6185): 750-754.

Clark DJ, Anderson DS. 2015. Past is Present: The Production and Consumption of Archaeological Legacies in Mexico. In Constructing Legacies of Mesoamerica: Archaeological Legacies and the Politics of Heritage in and Beyond Contemporary Mexico, Archeological Papers of the American Anthropological Association 25 (1): 1-18.

Coke JG. 2019. Underwater caves of the Yucatan peninsula. In Encyclopedia of Caves, 1089-1095. Cambridge: Academic Press.

Coggins CC. 1984. Cenote of Sacrifice: Maya Treasures from the Sacred Well at Chichen Itza. Austin, TX: University of Texas Press. ISBN: 0-292-71098-4.

Coggins CC. 1992. Artifacts from the Cenote of Sacrifice, Chichén Itzá, Yucatán: Textiles, Basketry, Stone, Bone, Shell, Ceramics, Wood, Copal, Rubber, Other Organic Materials, and Mammalian Remains. Cambridge, MA: Peabody Museum of Archaeology and Ethnology, Harvard
University; distributed by Harvard University Press. ISBN: 0-87365-694-6. OCLC: 26913402.

Dedrick M. 2018. Photovoice as a method for the development of collaborative archaeological practice. Journal of Community Archaeology and Heritage 5 (2): 85-100.

Freire P. 1970. Pedagogy of the oppressed, Trans. by M.B. Ramos. New York: Continuum.

Gavin MC, McCarter J, Mead A, Berkes F, Stepp JR, Peterson D, Tang R. 2015. Defining biocultural approaches to conservation. Trends in Ecology \& Evolution 30: 140-145. https://doi.org/10.1016/j. tree.2014.12.005.

Guillermoprieto A. 2013. Secrets of the Maya Otherworld. National Geographic 224 (2): 99-121.

Hernandez C, Vail G. 2013. The Role of Caves and Cenotes in Late Postclassic Maya Ritual and Worldview. Acta Americana 18: 13-45.

López-Maldonado Y, Berkes F. 2017. Restoring the environment, revitalizing the culture: cenote conservation in Yucatán, Mexico. Ecology and Society 22 (4): 7-20. https://doi.org/10.5751/ES09648-220407.

Love B. 2012. Maya Shamanism Today: Connecting with the Cosmos in Rural Yucatan. Precolumbia Mesoweb Press.

McAnany PA. 2016. Maya Cultural Heritage: How Archeologists and Indigenous Communities Engage the Past. Lanham, MD: Rowman and Littlefield.

McAnany PA, Parks S. 2012. Casualties of Heritage Distancing: Children, Ch'orti' Indigeneity, and the Copan Archaeoscape. Current Anthropology 53 (1): 80-107.

Thelen D, Morgan KL. 2015. Building a New South Africa: One Conversation at a Time. Bloomington and Indianapolis: Indiana University Press.

Wang C, Burris MA. 1997. Photovoice: Concept, Methodology, and Use for Participatory Needs Assessment. Health Education \& Behavior 24 (3): 369-387. 